\title{
Lepidagathis Keralensis: An Overview
}

\author{
Poornima M, Alan Jacob, Dr. AjithBabu T K, Malavika T.M \\ Malik Deenar College of Pharmacy, Kerala, India
}

\begin{abstract}
Lepidagathiskeralensis family Acanthaceaeis a plant endemic to Kerala. The genus comprises about 110 species, mainly distributed in tropical and subtropical countries with 33 species in India. It is a hard prostrate shrub with woody root stalk. It is found in lateritic hills near sea coast mainly in exposed lateritic rocks. Commonly it is known as Paramullu. Previous studies showed that, plant is a rich source of many bioactive constituents and it possesses medicinal properties. Here the review designed to point out the pharmacological effect of Lepidagathiskeralensis.
\end{abstract}

Keywords: Lepidagathiskeralensis, Acanthaceae, Pharmacology

\section{INTRODUCTION}

$\mathrm{M}$ edicinal plants also called medicinal herbs. An herb can be any form of a plant or plant product, including leaves, stems, flowers, root, and seeds. An herbal medicine may be defined as a plant derived products for medicinal and health purpose. Natural products, mainly plant have been used for the treatment of various disease for thousands of years. The secondary metabolites produced by the plants are responsible for the biological activity of the plant and used synthesis of different drugs. According to WHO, $80 \%$ of the people are depends on medicinal herb as a primary health care system. Drugs of natural origin can be safe, cost effective, easily available and more potent. ${ }^{[1,2]}$

Lepidagathis genus represented by 100 of species widely spread in tropical and subtropical regions of Asia and Africa.Lepidagathiskeralensis(Acanthaceae) is less explored plant for research studies.The family known to contain bioactive components likes cytotoxic, anti-fungal, antiinflammatory, anti-oxidant and insecticidal properties. The plant had many medicinal properties. The spines of the plant used by Paniya tribes for digestive disorders. The plant is also used for kidney stone, asthma, chest pain, blood purifieretc.The major isolated chemical constituents of the genus include essential oils, sesquiterpenes, flavanoids, phenolics, alkaloids, inorganic minerals and saponins. ${ }^{[3,4]}$

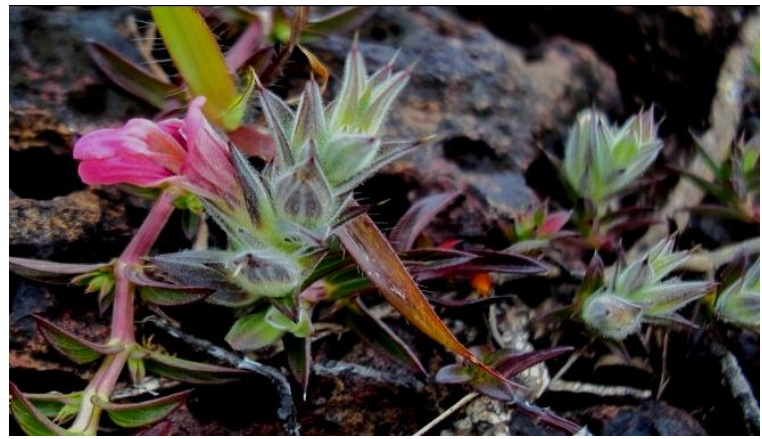

Fig 1: Lepidagathiskeralensis

\section{SCIENTIFIC CLASSIFICATION ${ }^{[5,6]}$}

Kingdom: Plantae

Phylum: Tracheophyta

Class: Magnolisidae

Order: Laminale

Family: Acanthaceae

Genus: Lepidagathis

Species: Lepidagathiskeralensis

Common Name

$\checkmark$ Kerala Lepidagathis

\section{Vernacular Name}

$\begin{array}{ll}\checkmark & \text { Nonganampullu } \\ \checkmark & \text { Paramullu } \\ \checkmark & \text { Venappacha }\end{array}$

Part used: Whole plant, stem, root and leaves

Flowering and fruiting: December-April

\section{DISTRIBUTION}

Global Distribution: South India (Kerala)

Indian Distribution: Kerala (Kannur- Ezhimala, Madayipara, Pazhayangadi)

Endemic Distribution: Southern Western Ghats

$$
\text { IV. DESCRIPTION }{ }^{[5,6]}
$$

\begin{tabular}{|l|l|}
\hline Habit & Herb \\
\hline Habitat & Laterirte hills near sea cost \\
\hline Root & $\begin{array}{l}\text { Woody rootstock } \\
\text { Glabrous, Quadrangular, More } \\
\text { or less winged }\end{array}$ \\
\hline Stem & $\begin{array}{l}\text { Simple, Opposite, } \\
10 \text { mm×3mm, narrowly } \\
\text { oblong-lanceolate, Acute or } \\
\text { blunt-acuminate at apex, Dark } \\
\text { green with purple margins }\end{array}$ \\
\hline Leaves & $\begin{array}{l}\text { Sessile,1cm long, Pink, Sterile } \\
\text { bracts(5-8), Oblong- } \\
\text { lanceolate, sharply pointed } \\
\text { spine }\end{array}$ \\
\hline Flowers & $\begin{array}{l}\text { Compressed capsule, 6mm } \\
\text { long }\end{array}$ \\
\hline Fruit & $\begin{array}{l}2 \text { seeds, flat, softly hairy with } \\
\text { white aril }\end{array}$ \\
\hline Seed
\end{tabular}




\begin{tabular}{|l|l|}
\hline Calyx & $\begin{array}{l}\text { Deeply 5-lobed, Lobe's } \\
\text { unequal, Persistent, Similar to } \\
\text { bracts }\end{array}$ \\
\hline Corolla & $\begin{array}{l}\text { 10cm long, 2-lipped, upper lip } \\
\text { 2-lobed, pink, lower lip 3- } \\
\text { lobed, pink with white to } \\
\text { yellow palate }\end{array}$ \\
\hline Stamens & $\begin{array}{l}\text { 4, up to 6mm long, Purple to } \\
\text { deep violet color }\end{array}$ \\
\hline Ovary & $\begin{array}{l}\text { Compressed ovoid,2mm long, } \\
\text { 2-celled with one ovule in } \\
\text { each }\end{array}$ \\
\hline Style & Slender,7-8mm long \\
\hline
\end{tabular}

\section{PHYTOCHEMICAL COMPOSITION ${ }^{[7]}$}

Previous studies of researchers on Lepidagathiskeralensis revealed different phytochemical composition. Different parts of Lepidagathiskeralensis are reported with alkaloids, carbohydrates, tannins, glycosides, saponins, phlobatannins, flavanoids, resins, sterols, amino acids, protein, phytosterols, phenols, Terpenes.

\section{PHARMACOLOGICAL ACTIVITY}

Antimicrobial Activity ${ }^{[8]}$

\section{Antibacterial activity}

Antibacterial activity was done by Agar well diffusion method in the plant parts of Lepidagathiskeralensis.Two-gram negative strains (Pseudomonas aeroginosa and Klebsiella pneumonia), two-gram positive strains (Streptococcus aureus, Streptococcus mutants) are used. $20 \mathrm{ml}$ of prepared Muller Hinton Agar medium was added to petriplate while it is hot. Nutrient agar was dispensed evenly as required. It is then autoclaved at $121^{\circ} \mathrm{c}$ for 15 minutes. The plates were then inoculated with bacterial culture. Wells are prepared on the plate, different concentration $(25 \mu \mathrm{g}, 50 \mu \mathrm{g}, 100 \mu \mathrm{g})$ of sample were added to this. Petri plates were incubated at $37^{\circ} \mathrm{c}$ for 24 $\mathrm{hr}$ and zone of inhibition (ZOI) around the well is measured.

Gram negative bacterium Klebsiella pneumonia is inhibited by acetone extract of the stem and methanol extract of leaf and the ZOI was found to be $16 \mathrm{~mm}$ and $15 \mathrm{~mm}$ respectively. Methanol extract of the leaf shows maximum zone of inhibition $20 \mathrm{~mm}$ against pseudomonas aeroginosa compared to acetone extract of the stem.

All extracts of leaf and stem were effective against gram positive bacteria Streptococcus mutans. Methanol extract showing maximum ZOI of $15 \mathrm{~mm}$.In the case of Staphylococcus aureus all extract showed similar activity. The present study high light the importance of plant against microbial infections.

\section{Antifungal activity ${ }^{[7]}$}

Antifungal activity is done by agar well diffusion method. Potato Dextrose agar plates were prepared and inoculated with fungus Candida albicans. Well, are prepared on the plates and different concentrations $(25 \mu \mathrm{g}, 50 \mu \mathrm{g}, 100 \mu \mathrm{g})$ of samples were added. The plates were incubated and zone of inhibition was measured. Methanol extracts of leaf and stem are effective against fungus. Zone inhibition was found to be $15 \mathrm{~mm}$ and 16 mmrespectively.

Antioxidant Activity ${ }^{[9]}$

\section{DPPH Assay}

Different extract (Pet.ether, acetone, methanol, aqueous) of leaf and stems of Lepidagathiskeralensis is used for measurement of antioxidant activity. DPPH is a stable free radical; the scavenging potential of the extract is measured by discoloration of DPPH in methanol. Different extracts of leaf and stem were tested for antioxidant activity. Decrease in absorbance indicates increase in antioxidant activity. Methanol extract of leaf and acetone extract of stem shows maximum inhibition of activity. Methanol extract shows 96.38\% ( $\left.\mathrm{IC}_{50}-122.46 \pm 0.85\right)$, acetone extract shows $86.46 \%\left(\mathrm{IC}_{50}-231.87 \pm 1.69\right)$. Therefore, different part of the plant mainly stems and leaf shows potent antioxidant activity.

\section{Reducing Power}

Antioxidant potential of the extract is determined by reduction of ferricyanide complex to ferrous, indicated by the color change from yellow to Perl Prussian blue colored complex. Absorbance is determined at $700 \mathrm{~nm}$. Comparing to the ascorbic acid standard (1.462); methanol extract of leaf(1.226) and acetone extract of stem( 0.826$)$ shows highest antioxidant potential.

\section{Determination of Total Phenolic Content (TPC)}

It is based on Folin-ciocalteu reagent method. 500 $\mu 1$ of Folinciocalteu is mixed with $100 \mathrm{ml}$ of plant extract. To this mixture add $1.2 \mathrm{ml}$ of $20 \%$ sodium carbonate. Make up to 10 $\mathrm{ml}$ using distilled water. Absorbance is measured at $765 \mathrm{~nm}$ using Gallic acid equivalent. Among the different extract (Pet. Ether, acetone, methanol, aqueous) tested for leaf and stem, methanol extract of leaf $(139.76 \pm 0.41 \mathrm{mg} \mathrm{GAE} / \mathrm{g})$ and acetone extract of stem $(102.00 \pm 1.40)$ contain maximum amount of TPC.

\section{Determination Of Total Flavanoid Content (TFC)}

Different plant extract (pet. Ether, acetone, methanol, aqueous) are tested for total flavanoid content by Aluminum chloride colorimetric method. $1 \mathrm{ml}$ of sample was dissolved in $4 \mathrm{ml}$ distilled water. $0.3 \mathrm{ml}$ of $\mathrm{NaNO}_{2}$ solution was added, $0.3 \mathrm{ml}$ of $\mathrm{Alcl}_{3}$ was added. After $6 \mathrm{~min} 2 \mathrm{ml}$ of $\mathrm{NaOH}$ solution was added, mix well and absorbance of the solution is measured at $510 \mathrm{~nm}$. Rutin is used as standard. Different extract tested, methanol extract of leaf contained highest amount of TFC $(258.33 \pm 1.47 \mathrm{mg} \mathrm{RE} / \mathrm{g})$ and acetone extract of stem (240.00 $\pm 2.42 \mathrm{mg} \mathrm{RE} / \mathrm{g}$ ) 


\section{REFERENCES}

[1]. Ali Sobhanizadeh, HoshangYadegari, BahmanFazeli-nsaab, BarataliFakheri. Introduction on application of herbal medicine. The $1^{\text {st }}$ annual Iranian agriculture research coference.2015 July; 111.

[2]. RefazAhmd Dar, MohmdShahnawaz, Parvaiz Hassan Qazi. General overview of medicinal plants. A review the journall of phytopharmacology.2017;6(6):349-351.

[3]. Sharmila. S, Nalli. R, Surumbayee. M, Ramya. EK. GC-MS Analysis of bio-active components in petroleum ether extract of Lepidagathisscariosa (Nees.)-Acanthaceae. IJPR.2019 Feb;54(1):56-63.

[4]. PalakkalLeena, N.H. ZeinulHukuman, A.R. Biju, MullapallyJisha. Studies on methanolic extract of Lepidagathiskeralensis as a green corrosion inhibitor for mild steel in $1 \mathrm{M} \mathrm{HCl}$. Journal of electrochemical science and technology. 2019 Jan;10(2): 231-243.
[5]. P.V Madhusoodanan, N.P Singh. A new species of Lepidagathiskeralensis(Acanthaceae) from south India. New bulletin.1992;27(2):301-303.

[6]. Lepidagathiskeralensis. Kerala plants. in. 2018 Mar.

[7]. P.M. BeebiRazeena, M.Mini.Bioefficiency and phytochemical analysis of Lepidagathiskeralensis of Acanthaceae. World journal of pharmaceutical and sciences.2017Apri; 3(2):124-126.

[8]. Leena. P, ZeinulHukman N H, Jisha. M. Evaluation of antimicrobial activity of crude extract of Lepidagathiskeralensis. IJRP. 2017;8(3):321-326

[9]. LeenaPalakkal, ZeinulHukuman. N.H, Jisha. M. Antioxidant activities and chemical composition of various extracts of Lepidagathiskeralensis. Journal of Applied Pharmaceutical science. 2017 June; 7(06): 182-189. 